\title{
Observations on Plant Health Clinic: Diversification for Strengthening Food Security
}

\author{
MP Srivastava* \\ Formerly Director and Head Plant Pathology, Haryana agricultural University, India
}

Received: 畊 May 02, 2018; Published: 㘹 May 18, 2018

*Corresponding author: MP Srivastava, Formerly Director and Head Plant Pathology, Haryana agricultural University, India

\section{Introduction}

Due to unabated rise in population, more so in Afro-Asian and Latin American countries food security has become a matter of concern. It is expected that global population may reach 10 billion and therefore globally all efforts are to be made to produce enough food to meet the growing requirement of the population. Unabated rise in population is also responsible for land-crunch, making the task a little difficult. In addition, changing climate and more importantly plant pests and diseases pose serious threat to food security. Plant diseases appear to be the biggest threat to food security. Several diseases in the past, such as late blight of potato in 1845 in Ireland, Coffee rust in Sri Lanka in 1876, Brown Leaf Spot of rice in 1942 in India caused untold miseries. The list is not complete; these are some of the examples. Worldwide plant pests are responsible for $40 \%$ losses in yield. To ensure sustained productivity from limited land, it is important to employ innovative technology for food production commensurate to meet the food requirement of ever growing population and modern know-how on plant health from plant health clinic (PHC), which plays a vital role in mitigating losses and assuring food security by timely providing diagnostic and rendering need based prescription.

Plant clinics are in operation as walk-in -clinic (like Plant Health Camp) operating in market places, under Global Plant Clinic Programme (now Plantwise Initiative since 2010) across the world. Besides Plant clinics are also in operation at fixed location in their own building as in USA, Canada, and India. Plant clinics at permanent location have been developed modeled on human clinics, yet PHC have yet to receive public attention since their number is inadequate as compared to human clinics. However, National Horticulture Mission of Government of India has further accelerated the growth of PHC in a big way. Let others follow suit. The author in his Keynote Address in $10^{\text {th }}$ International Congress of Plant Pathology in August 2013 in Beijing, China called upon various nations to create more Plant Clinic at subdivision level in the district providing easy access to growers to efficiently

protect their crop frm onslaught of diseases and pests. Earlier in 1990 in China in a special lecture in an international Conference concluded, let the dawn of $20^{\text {th }}$ Century witness the Plant Clinic as global phenomenon, but we have not to be complacent and go ahead diversifying. It was such a important task that he organized an Evening session on Plant Health Clinic at Turin, Italy during $9^{\text {th }}$ ICPP involving world scientist.

Why PHC is considered important? Truly PHC provide diagnostic and advisory role, offer training of farmers on field diagnosis of pests, Efficient pest management techniques involving pesticides and IPM., pesticides resistance, plant disease surveillance and monitoring pest outbreak, keeping a vigil on entry of alien pests and producing Plant Doctors \& Para-Plant Health Aids, keeping liaison with development and scientific agencies A good plant doctor may command the same respect as a physician gets in the society. 


\section{(C) (1) \\ This work is licensed under Creative \\ Commons Attribution 4.0 License}

To Submit Your Article Click Here: Submit Article

DOI: 10.32474/CIACR.2018.02.000147

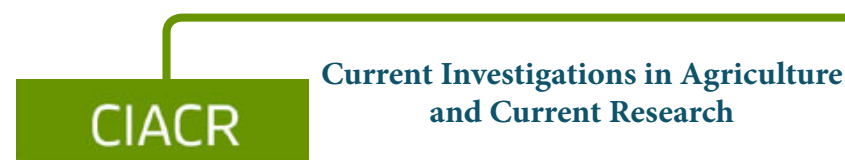

\section{Assets of Publishing with us}

- Global archiving of articles

- Immediate, unrestricted online access

- Rigorous Peer Review Process

- Authors Retain Copyrights

- Unique DOI for all articles 